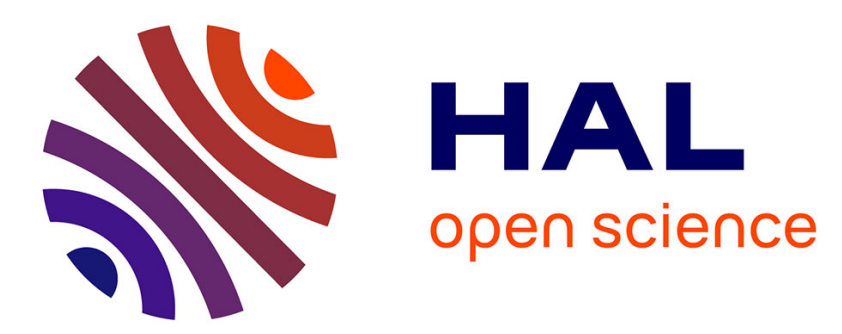

\title{
Caractérisation et croissance de monocristaux D-KDP utilisés comme modulateurs électro-optiques dans les dispositifs a restitution d'image
}

\author{
C. Belouet
}

\section{- To cite this version:}

C. Belouet. Caractérisation et croissance de monocristaux D-KDP utilisés comme modulateurs électrooptiques dans les dispositifs a restitution d'image. Revue de Physique Appliquée, 1975, 10 (6), pp.362362. 10.1051/rphysap:01975001006036201 . jpa-00243927

\section{HAL Id: jpa-00243927 https://hal.science/jpa-00243927}

Submitted on 1 Jan 1975

HAL is a multi-disciplinary open access archive for the deposit and dissemination of scientific research documents, whether they are published or not. The documents may come from teaching and research institutions in France or abroad, or from public or private research centers.
L'archive ouverte pluridisciplinaire HAL, est destinée au dépôt et à la diffusion de documents scientifiques de niveau recherche, publiés ou non, émanant des établissements d'enseignement et de recherche français ou étrangers, des laboratoires publics ou privés. 


\title{
CARACTÉRISATION ET CROISSANCE DE MONOCRISTAUX D-KDP UTILISÉS COMME MODULATEURS ÉLECTRO-OPTIQUES DANS LES DISPOSITIFS A RESTITUTION D'IMAGE
}

\author{
C. BELOUET
}

Laboratoires d'Electronique et de Physique Appliquée 3, avenue Descartes, 94450 Limeil-Brévannes, France

\begin{abstract}
Résumé. - Les hétérogénéités spatiales du déclin des images gardées en mémoire dans les tubes à restitution d'images (dont Titus) utilisant des cristaux D-KDP comme modulateurs électrooptiques sont généralement attribuées à des hétérogénéités de conductibilité électrique dans ces cristaux. Cet article montre que les hétérogénéités de conductibilité, révélées par une technique d'électrolyse, sont dues à une extrême sensibilité des coefficients de ségrégation des impuretés aux contraintes élastiques qui sont associées à certains défauts cristallins. Après avoir présenté quelques résultats sur la contribution d'impuretés particulières, dont le fer, à la conductibilité, on discute de l'origine des défauts cristallins, tels qu'ils sont révélés en topographie de rayons $\mathrm{X}$, en fonction des conditions de croissance et de la préparation des germes. Sur la base des résultats acquis, les conditions nécessaires à l'obtention de monocristaux très deutériés, de grande taille et satisfaisant aux applications ci-dessus, sont brièvement commentées.
\end{abstract}

Abstract. - The non-uniform decay of pictures stored by means of large screen display devices (such as Titus) which use D-KDP targets as electro-optical modulators, is generally ascribed to conductivity heterogeneities in the crystals. It is shown in this article that conductivity heterogeneities, revealed by means of an electroding technique for instance, are consecutive to an extreme sensitivity of the segregation of the impurities with respect to elastic strains due to specific crystal defects. Results concerning the contribution of particular impurities, e. g. the iron, to the electrical conductivity are presented and the origins of crystal defects (as they are revealed in X-Ray topographs) are discussed in relation to the growth conditions and the seed preparation successively. On the basis of these results, the most appropriate growth conditions for obtaining large single crystals suitable for the above applications are briefly reviewed. 